Magdalena Mazur ${ }^{1}$, Robert Ulewicz ${ }^{2}$

\title{
INNOVATIVE MATERIALS IN CONSTRUCTION OF SEMITRAILERS CAR
}

\begin{abstract}
In this work are defined steels requirements, which are used in the construction of semi-trailers car. Mechanical properties and fatigue of selected high-strength steel are shown in the paper. Complete characterization of the tested materials will be the base to identify new applications of these material in the construction of semi-trailers. From the practical point of view the durability of some components in the automotive industry and similar technical applications such as special semitrailers is ranging between $10^{8}$ and $10^{10}$ cycles. But, only few experimental results beyond $10^{7}$ cycles are available now. The main objective of this research was to provide independent results to the company which uses Hardox steel in the construction of semitrailers.
\end{abstract}

Key words: high-strength steel, mechanical properties, fatigue properties, semi-trailers

\section{Introduction}

WIELTON S.A. is Poland's biggest semi-trailers and trailers producer, and one of the 10 leading producers in Europe. The company pioneers in implementation of the latest manufacturing technologies in semi-trailer industry in Poland. Thanks to modern production facilities, production process automation and robots, WIELTON S.A. can compete with international companies in terms of quality and product range. The company offers the highest range of products on polish market with more than 60 types of transport vehicles adapted to individual requirements of every client. Analyzing the products of leading manufacturers of semitrailers including products Wielton S.A., it can be observed the tendency to use steel characterized by increased resistance to abrasion such as steel Hardox, easily weldable steels. Shall also apply solutions

\footnotetext{
${ }^{1}$ Mgr inż., Częstochowa University of Technology, Faculty of Management, Institute of Production Engineering, e-mail: mazur.m@zim.pcz.pl

${ }^{2}$ Dr hab. inż., prof. P.Cz., Częstochowa University of Technology, Faculty of Management, Institute of Production Engineering, e-mail: ulewicz@ zim.pcz.pl
} 
to reduce the weight of the trailer. All these treatments aim to increase the technical objects lifetime. Increased competition in the market of semitrailers forces manufacturers to design new solutions and used new materials.

Based on research which are realized by WIELTON S.A. it can be formed a list of requirements for materials used to construction of semitrailers with particular emphasis on the requirements posed by the construction of tippers. Such materials must have features: very high resistance to abrasive, the ability to transfer variable workloads, uniform properties throughout the cross-section of the element, as well as susceptibility to connect using the welding techniques, and ease of cold forming.

\section{Material}

Article contains the results of tests on qualified steel. According to the manufacturer's information chemical composition and mechanical properties were presented in Table 1.

Table 1. Chemical composition and mechanical properties of researched material

\begin{tabular}{|c|c|c|c|c|c|c|c|c|c|}
\hline \multirow{6}{*}{ 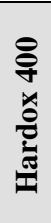 } & \multicolumn{9}{|c|}{ Chemical composition max [\%] } \\
\hline & $\mathrm{C}_{\max }$ & $\mathrm{Si}_{\max }$ & $\mathrm{Mn}_{\max }$ & $\mathrm{P}_{\max }$ & $\mathrm{S}_{\max }$ & $\mathrm{Cr}_{\max }$ & $\mathrm{Ni}_{\max }$ & $\mathrm{Mo}_{\max }$ & $\mathrm{B}_{\max }$ \\
\hline & 0.14 & 0.70 & 1.60 & 0.025 & 0.010 & 0.30 & 0.25 & 0.25 & 0.004 \\
\hline & \multicolumn{9}{|c|}{ Mechanical properties } \\
\hline & \multirow{2}{*}{\multicolumn{3}{|c|}{$\frac{\mathrm{R}_{\mathrm{e}}[\mathrm{MPa}]}{1000}$}} & \multicolumn{3}{|c|}{$\mathrm{R}_{\mathrm{m}}[\mathrm{MPa}]$} & \multicolumn{3}{|c|}{ A5 [\%] } \\
\hline & & & & & 1.250 & & \multicolumn{3}{|c|}{10} \\
\hline \multirow{6}{*}{ 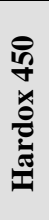 } & \multicolumn{6}{|c|}{ Chemical composition max } & & & \\
\hline & $\mathrm{C}_{\max }$ & $\mathrm{Si}_{\max }$ & $\mathrm{Mn}_{\max }$ & $\mathrm{P}_{\max }$ & $S_{\max }$ & $\mathrm{Cr}_{\text {max }}$ & $\mathrm{Ni}_{\text {max }}$ & $\mathrm{Mo}_{\max }$ & $\mathrm{B}_{\max }$ \\
\hline & 0.26 & 0.7 & 1.6 & 0.025 & 0.010 & 1.4 & 1.5 & 0.6 & 0.005 \\
\hline & \multicolumn{9}{|c|}{ Mechanical properties } \\
\hline & \multirow{2}{*}{\multicolumn{3}{|c|}{$\mathrm{R}_{\mathrm{e}}[\mathrm{MPa}]$}} & \multicolumn{3}{|c|}{$\mathrm{R}_{\mathrm{m}}[\mathrm{MPa}]$} & \multicolumn{3}{|c|}{ A5 [\%] } \\
\hline & & & & \multicolumn{3}{|c|}{1.400} & \multicolumn{3}{|c|}{10} \\
\hline
\end{tabular}




\begin{tabular}{|c|c|c|c|c|c|c|c|c|c|}
\hline \multirow{6}{*}{ 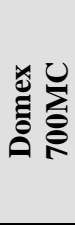 } & \multicolumn{9}{|c|}{ Chemical composition max [\%] } \\
\hline & $\mathrm{C}$ & $\mathrm{Si}$ & $\mathrm{Mn}$ & $\mathrm{P}$ & $\mathrm{S}$ & $\mathrm{Al}$ & $\mathrm{Nb}$ & $\mathrm{V}$ & $\mathrm{Ti}$ \\
\hline & 0.12 & 0.10 & 2.10 & 0.025 & 0.010 & 0.015 & 0.09 & 0.20 & 0.015 \\
\hline & \multicolumn{9}{|c|}{ Mechanical properties } \\
\hline & \multirow{2}{*}{\multicolumn{3}{|c|}{$\frac{\mathrm{R}_{\mathrm{e}}[\mathrm{MPa}]}{700}$}} & \multicolumn{3}{|c|}{$\mathrm{R}_{\mathrm{m}}[\mathrm{MPa}]$} & \multicolumn{3}{|c|}{ A5 [\%] } \\
\hline & & & & & $750-95$ & & \multicolumn{3}{|c|}{12} \\
\hline \multirow{6}{*}{ 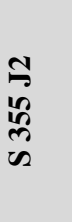 } & \multicolumn{6}{|c|}{ Chemical composition max } & & & \\
\hline & $\mathrm{C}$ & & $\mathrm{Si}$ & $\mathrm{M}$ & & $\mathrm{P}$ & $\mathrm{S}$ & & $\mathrm{Cu}$ \\
\hline & 0.22 & & 0.55 & 1. & & 0.03 & 0.03 & & 0.55 \\
\hline & \multicolumn{9}{|c|}{ Mechanical properties } \\
\hline & \multirow{2}{*}{\multicolumn{3}{|c|}{$\frac{\mathrm{R}_{\mathrm{e}}[\mathrm{MPa}]}{355}$}} & \multicolumn{3}{|c|}{$\mathrm{R}_{\mathrm{m}}[\mathrm{MPa}]$} & \multicolumn{3}{|c|}{ A5 [\%] } \\
\hline & & & & \multicolumn{3}{|c|}{$470-630$} & \multicolumn{3}{|c|}{22} \\
\hline
\end{tabular}

Source: manufacturer's data

S355J2 steel is mainly used to produce general-purpose welded elements. This material is used for parts of machinery in the building industry, construction components, carriages, large diameter pipes, etc. S355J2 steel has good welding properties, which contributes to its wide range of technical uses.

According to the manufacturer information, Hardox steels are defined as "high-quality abrasion-resistant steels". They are characterized by high resistance to abrasive wear, the possibility of specialized machining tools, good weldability, excellent mechanical properties and resistance to impact loads. Hardox steels are produced in six types. Among the six types of materials most widely used in the construction of tippers is Hardox 400 and 450 (PĘKALSKI G. 2005, OSKWAREK M. 2006). Hardox sheet according to the manufacturer's declaration can be welded using any conventional method of arc welding, which is used for welding normal and high strength steel. In the process of welding should be used basic and rutile electrodes, which giving the hydrogen content $\leq 5 \mathrm{ml} /$ 100 g. Producer recommend using a soft electrode (yield strength below $500 \mathrm{~N} / \mathrm{mm} 2$ ). Such electrodes reduce the level of residual tension in the weld and thus also reduces its susceptibility to cracking in low temperatures. In order to avoid pre-heating should be used the austenitic filler (SSAB Oxelösund 2002). 
Domex cold forming steels are rolled in a thermomechanical process, where the heating, rolling and cooling are carefully controlled. The chemical composition of the steel containing low levels of carbon and manganese, is precisely complemented by enriching ingredients such as niobium, titanium and vanadium. In combination with a clean structure, makes Domex steel is the best alternative for cold formed and welded products. Domex $700 \mathrm{MC}$ with designation D and $\mathrm{E}$ meet and even exceed the requirements for steel S700 MC according to the standard EN10149-2 (WIELTON 2001).

Extra high strength steels are used in structures such as truck chassis, cranes and excavators. In these applications, high strength steel is used in order to reduce weight while simultaneously increasing load capacity of the structure. These advantages, combined with good formability allow the reduction of total costs. Due to the low content of carbon, phosphorus and sulfur Domex $700 \mathrm{MC}$ steel can be welded by all commonly used methods (SZALA J., BOROŃSKI D. 2008).

In Fig. 1 was presented a pictorial diagram for tipper construction with application of above-mentioned materials.

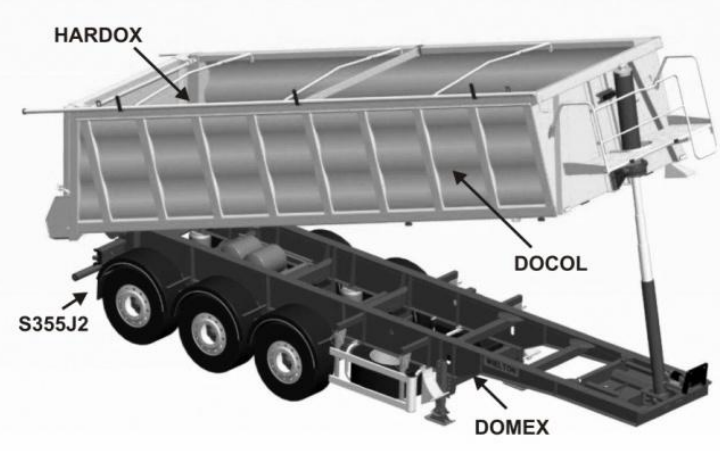

Fig. 1. Pictorial diagram of tipper NW 33S-M2 with application new grades of steel.

Source: Wielton S.A. company's data 
In production of tippers the following grades of steel are applied (MAZUR M., UlEWICZ R., SZATANIAK P. 2012):

- the floor, structural reinforcement, vault ribbing - S700MC,

- body panelling - Docol 1000DP,

- elements that not having the influence on construction (e.g. the handle of outline lamps, entrance steps) - S235JGR2, S355J2,

- elements of the load-bearing structure - Domex,

- elements which are subjected to abrasion - Hardox.

\section{Research}

Static tensile test has been made to determine the basic strength properties (yield strength $R_{e}$, tensile strength $R_{m}$, elongation $A_{5}$ and contraction $\mathrm{Z}$ ) of the analyzed materials. These tests were performed in the fatigue laboratory of the University of Zilina. Research were performed on a Zwick Z050 tensile testing machine at ambient temperature $\mathrm{T}=20 \pm 3{ }^{\circ} \mathrm{C}$, with operation load range $\mathrm{F}=0 \div 20 \mathrm{kN}$ and speed of tensile $\varepsilon_{m}=10^{-3} \cdot \mathrm{s}^{-1}$. Circular specimens which were used in the tests were made parallel to the direction of rolling. The shape and dimensions of the samples were determined according to the requirements of the standard EN 10002-1. The behavior of the test material while trying to best illustrated by the graph automatically plotted by the tensile test machine.

Figure 2 presents the representative curves of the tested materials, which have been determined based on the conducted of static tensile tests. Shapes curves for high-strength materials that have been received during the tests, are typical for strengthened materials - due to the structure and mechanical properties of the tested materials, in delivery state they do not show a clear yield point. The test results of structural steel S355J2 are characterized by a graph with a distinct upper and lower yield point. Static tensile test is the basic source of information about the mechanical properties of the tested materials, which are presented in Table 2. 


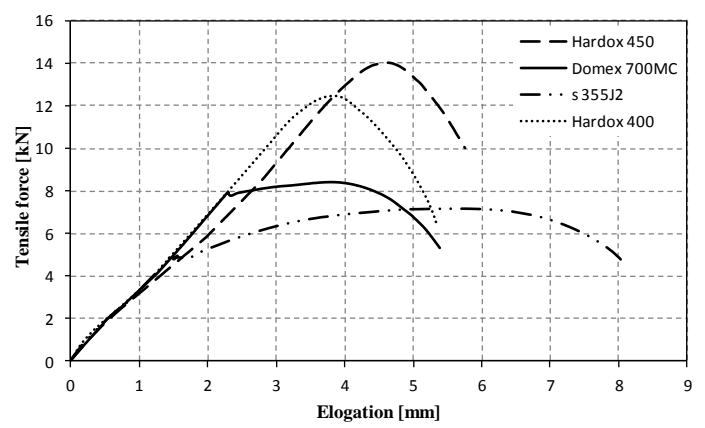

Fig. 2. Stress-strain curve for research materials in static tensile tests. Source: own study

Table 2. Results of static tensile tests for research materials

\begin{tabular}{|l|c|c|c|c|}
\hline \multicolumn{1}{|c|}{ Material } & $\begin{array}{c}\mathbf{R e} \\
{[\mathbf{M P a}]}\end{array}$ & $\begin{array}{c}\mathbf{R m} \\
{[\mathbf{M P a}]}\end{array}$ & $\begin{array}{c}\mathbf{A}_{\mathbf{5}} \\
{[\mathbf{\%}]}\end{array}$ & $\begin{array}{c}\mathbf{Z} \\
{[\mathbf{\%}]}\end{array}$ \\
\hline S355J2 & 420 & 715 & 22 & 59,2 \\
\hline Domex 700MC & 850 & 825 & 13,1 & 36 \\
\hline Hardox 400 & 1200 & 1235 & 12,8 & 36 \\
\hline Hardox 450 & 1425 & 1560 & 13,5 & 38 \\
\hline
\end{tabular}

Source: own study

One of the reasons for the current interest in very fine grained metallic materials is the concept that control of the mechanical properties by processing may be more desirable than the current practice of controlling properties by alloying (CHAPETTI M. D. et all 2004, TRŠKO L. et all 2012). For fatigue tests was used experimental equipment KAUP-ŽU Žilina. Used testing methods and procedures are described elsewhere (BOKŮVKa O., et all. 2002., STANZL-TSCHEGG S., MAYER H. 2001, BORKOWSKI S. et all 2011, PUŠKÁR A. 1990). The experiments were carried out on resonant high-frequency fatigue machine in the regime of controlled load using sinusoidal tension-compression loading with the frequency of $20 \mathrm{kHz}$. The stress ratio of $\mathrm{R}=-1$ was used. Fatigue tests were performed at the ambient temperature $\left(T=20 \pm 3^{\circ} \mathrm{C}\right)$. 
Specimens were cooled by distilled water with anticorrosive inhibitor (BoKŮVKa O., Novy F. 2004). Specimen shape and dimension were determined according to the Salama and Lamerand technique (SALAMA K., LAMERAND R.K. 1982, KUNZ L. 2003.). Shape of the sample is shown in Figure 3. The details, especially about methods and procedures the fatigue high-frequency parameters measuring can be found in the (PUŠKÁR A. 1990, MIKOVÁ K. et all. 2012, BOKŮVKA O. et all. 2010). Shape of the sample is shown in Figure 3. Fatigue tests were aborted in region more than $\mathrm{N}=10^{5}$ cycles. The results of fatigue tests are shown in Fig. 4.

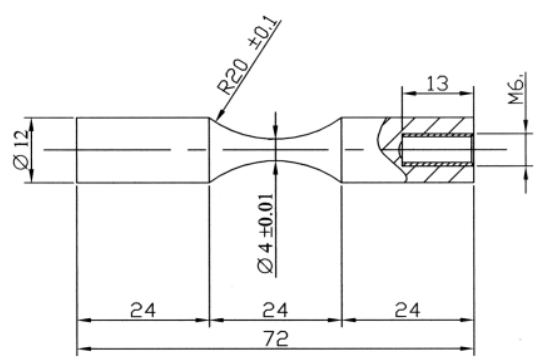

Fig. 3. Shape and size of the sample.

Source: own study

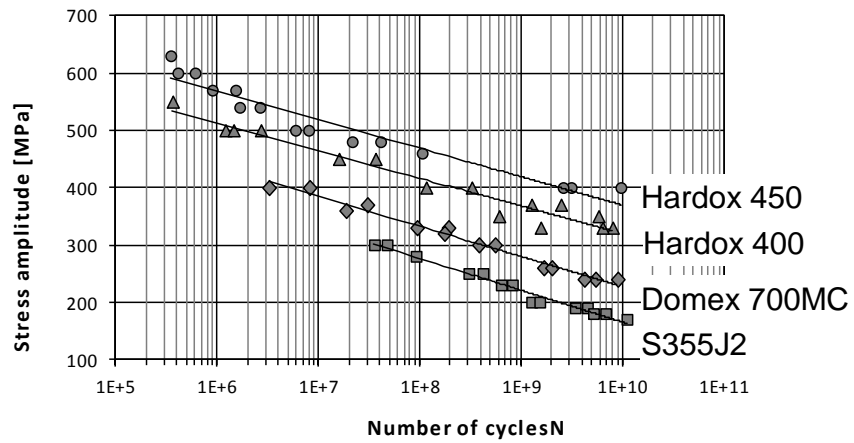

Fig. 4. Fatigue lifetime of researched steels loaded in tension compression at high frequency loading $\left(f=20 \mathrm{kHz}, \mathrm{T}=20 \pm 10^{\circ} \mathrm{C}, \mathrm{R}=-1\right)$.

Source: own study 
The amplitude of load fatigue testing Domex $700 \mathrm{MC}$ decreased from $\sigma_{a}=400 \mathrm{MPa}$ (for $N_{f}=3.3 \cdot 10^{6}$ and $N_{f}=8.1 \cdot 10^{6}$ number of cycles) to $\sigma_{a}=$ $240 \mathrm{MPa}$ (for $N_{f}=4.1 \cdot 10^{9}, N_{f}=5.4 \cdot 10^{9}$, and $N_{f}=8,9 \cdot 10^{9}$ number of cycles), which gives their differences in amplitude $\Delta \sigma_{a}=160 \mathrm{MPa}$. Examination of the specimens (UHC) which have been made from the material analyzed showed that the decrease the amplitude of loads increases the number of cycles N (BATHIAS C., DROUILlaC I., FRANCOIS P.L. 2001). Stress amplitude at the level of $630 \mathrm{MPa}$ caused the fractured specimens in two trials. These cracks were created at the number of cycles accordingly 600 and 400 thousand cycles. The lowest amplitude applied at $455 \mathrm{MPa}$ resulted in cracks of three further specimens in the number of cycles above $N_{f}=2 \times 10^{9}$. Above conventional fatigue limit of materials the results of further studies confirm the strong correlation of decreasing amplitude loading samples with increasing number of cycles to failure.

\section{Conclusion}

Conducted research are intended to facilitate responses to constructors using Hardox steels, which is a safe operation life of structural elements made of steel Hardox in terms of fatigue wear. There were conducted researches in the area of UHC at resonance fatigue testing machine KAUP-ZU. The continuous increase of lifetime was observed with decreasing stress amplitude. The fatigue properties of Hardox strongly depend on the martensitic transformation conditions. The increase of the tensile strength is not accompanied by corresponding increase of fatigue properties.

Hardox Steels are a new generation of materials with properties (such as wear resistance) are obtained during the a very complex manufacturing process. These properties should be used after having an accurate diagnosis of their behavior under real operating conditions of use. Hardox Steels should be used without additional treatment such as was provided by the mill. This applies especially to those elementsin which is very 
important to the efficient use of their resistance to abrasive wear (eg, the impact of inappropriate treatments heat affected zone during welding affects the mechanical properties. Domex is the best alternative for use in the manufacture of cold formed and welded products. The research and experience of Wielton S.A. demonstrate the possibility of the use of finegrained Hardox 400 and 450 steels in building of semi-trailers. The use of wear-resistant materials, extends the life and also reduces the weight of a trailer thanks to thinner sheets used for construction of trailers.

\section{Bibliography}

1. Bathias C., Drouillac I., Francois P.L. 2001. How and why the fatigue $S-N$ curve does not approach a horizontal asymptote. International Journal of Fatigue Vol. 23, No. 1. s. 143-151.

2. BokŮvka O., Nicoletto G., Kunz L., Palcek P., Chalupova M. 2002. Low \& high frequency fatigue testing. CETRA and Univerzity of Zilina, Zilina.

3. BOKŮVKa O., NOvy F. 2004. Vysokocyklová únava a gigacyklove režimy, Letná škola únavy materiálov `2004, Zuberec.

4. BokU゚VKa O., NovÝ F., Mintach R., ČInČala M. 2010. Influence of loading type on the shape of life time curie. International Journal of Applied Mechanics and Engineering, Vol. 15/2010, No. 2, s. 321-328.

5. BorkowsKi S., UleWICZ R., MAZUR M. 2011. Use of Objective Function to Choice of Material for Building Development of Railway, In: SEMDOK 2011. 16th International of PhD. Students' Seminar. Zilina - Terchova, Slovakia.

6. Chapetti M.D., Miyata H., Tagawa T., Miyata T., Fujioka M. 2004. Fatigue strength of ultra-fine grained steel. Materials Science and Engineering: A Volume 381, Issues 1-2, p. 331-336

7. Cięcie gazowe, spawanie. Hardox, Weldox. Materiały informacyjne huty SSAB Oxelösund 2002.

8. KUNZ L. 2003. Experimentální stanovení únavových charakteristik materiálů. EDIS. Žilina. 
9. MaZUR M., Ulewicz R., SzataniaK P. 2012. Właściwości zmęczeniowe wybranych gatunków stali stosowanych $w$ konstrukcjach naczep samochodowych. W:Prace XL Szkoły Inżynierii Materiałowej. Monografia pod red. Jerzego Pacyny. s.64-68, Wydawnictwo Naukowe AKAPIT, Kraków.

10. MikovÁ K., NovÝ F., TrŠKO L., BOKU゚VKA O. 2012. Únavová životnost mikrolegovaných oceli pre potrubia určené na transport zemného plynu. In: SEMDOK 2012. 17th International of PhD. Students' Seminar. Zilina Terchova, p. 193-196, EDIS University of Žilina.

11. OSKWAREK M. 2006. Structural features and susceptibility to cracking of welded joints of Hardox 400 and Hardox 500 steels. Materiały Konferencji Naukowej SKN, Wrocław.

12. PĘKALSKI G. 2005. Wybrane zagadnienia materiałowe elementów maszyn górnictwa odkrywkowego narażonych na zużywanie ścierne a możliwości zastosowania stali Hardox, Górnictwo Odkrywkowe, Nr 4-5.

13. PUŠKÁR A. 1990. Metodika práce na zariadení KAUP, Žilina.

14. SAlama K., LAmERAnd R.K. 1982. Ultrasonic fatigue, Conf. Proc., The Met. Soc. of AIME, New York.

15. StAnZL-TschegG S., MAYeR H. 2001. Fatigue in the very high cycle regime, Vienna, Austria.

16. SzALA J., BOROŃSKI D. 2008. Ocena stanu zmęczenia materiału $w$ diagnostyce maszyn $i$ urzadzeń. Uniwersytet TechnologicznoPrzyrodniczy. Bydgoszcz.

17. TrŠKo L., Miková K., NovÝ F., BoKŮVKA O. 2012. Gigacycle fatigue of selected structural materials. W: SEMDOK 2012 : 17th international of PhD. student's seminar: Žilina - Terchová, Slovakia, 25-27 January, 2012. - Žilina: University of Žilina.

18. WIELTON S.A. 2011. Materiały informacyjne. Wieluń. 